\title{
Minat Peserta Didik dalam Mengikuti Pembelajaran PJOK pada Masa Pandemi Covid-19
}

\author{
I Wayan Suprianto ${ }^{1 *}$, H. Wahjoedi ${ }^{2}$, Ni Luh Putu Spyanawati ${ }^{3}$ iD \\ ${ }^{123}$ Jurusan Pendidikan Olahraga, Universitas Pendidikan Ganesha, Indonesia \\ *Corresponding author: wayansuprianto202@gmail.com
}

\begin{abstract}
Abstrak
Pembelajaran pendidikan jasmani mengalami perubahan selama periode pandemi Covid 19 dan pada masa New Normal, sehingga menjadi penting untuk mengetahui minat siswa dalam mengikuti pembelajaran pendidikan jasmani pada masa New Normal Covid.19. Penelitian ini bertujuan untuk mengetahui minat peserta didik dalam mengikuti pembelajaran PJOK pada masa pandemi covid-19. Penelitian ini termasuk jenis penelitian deskriptif dengan pendekatan kuantitatif. Metode pengumpulan data menggunakan metode survey, sedangkan jenis survey yang digunakan yaitu survey kuisioner yang dijawab oleh peserta didik. Populasi dalam penelitian ini adalah seluruh peserta didik kelas VIII SMP Negeri 5 Singaraja, dengan jumlah 300 orang, sementara sampel dipilih berdasarkan convenience sampling yang ini diambil $20 \%$ dari populasi penelitian, dimana total sampelnya adalah sebanyak 60 orang. Analisis data yang digunakan dalam penelitian ini yaitu menggunakan statistik deskriptif kuantitatif kemudian dikategorikan berdasarkan skala penilaian. Berdasarkan analisis data pada minat peserta didik dalam mengikuti pembelajaran PJOK mendapatkan skor 81 dimana pada skala penilaian kategori, angka tersebut dinyatakan sangat tinggi.
\end{abstract}

Kata Kunci : Minat, Pembelajaran PJOK, Pandemi Covid-19

\section{Abstract}

Physical education learning has changed during the Covid 19 pandemic period. During the New Normal period, it is important to know students' interest in participating in physical education learning during the New Normal Covid 19 period. This study aims to determine the interest of students in participating in PJOK learning during the covid-19 pandemic. This research is descriptive research with a quantitative approach. The data collection method used the survey method, while the type of survey used was a questionnaire survey answered by students. The population in this study were all eighth-grade students of SMP Negeri 5 Singaraja, with 300 people. At the same time, the sample was selected based on convenience sampling, which took $20 \%$ of the study population, where the total sample was 60 people. The data used in this study used quantitative descriptive statistics and then categorized based on the rating scale. Based on data analysis on students' interest in participating in PJOK learning, they get a score of 81 . On the category rating scale, the number is stated to be very high.

Keywords: interest, Physical Education Learning (PJOK), Pandemic Covid-19.

$\begin{array}{ll}\text { History: } & \text { Publisher: Undiksha Press } \\ \text { Received: 24 Maret } 2020 & \text { Licensed: This work is licensed under } \\ \text { Revised: } 15 \text { April } 2020 & \text { a Creative Commons Attribution 3.0 License } \\ \text { Accepted: } 17 \text { Mei } 2020 & \text { CC (O) }\end{array}$




\section{Pendahuluan}

Sumber Daya Manusia (SDM) merupakan salah satu hal yang sangat penting dikembangkan dalam menghadapi persaingan di era globalisasi ini. Mengembangkan sumber daya manusia dapat dilakukan dengan beberapa faktor. Salah satunya yaitu dengan pendidikan. Melalui sektor pendidikan, manusia diharapkan mampu mewujudkan segala potensi yang ada didalam dirinya. Pendidikan sudah didapatkan sejak kita terlahir di dunia ini. Keluarga adalah pendidikan yang utama dan pertama yang didapatkan oleh anak, sebelum akhirnya nanti anak mengenal dunia pendidikan secara formal. Perkembangan zaman yang semakin maju, ditambah perkembangan globalisasi yang tidak terkendali mengharuskan membentuk pendidikan yang berkualitas (Wirayasa, 2020)

Pendidikan jasmani (Penjas) merupakan pendidikan yang dapat mendukung pencapaian tujuan pendidikan secara keseluruhan. Penjas memiliki potensi untuk mengembangkan domain-domain yang meliputi: kognitif, afektif, psikomotor, dan fisik. Penjas merupakan pendidikan melalui aktivitas fisik dengan menggunakan medium kegiatan dalam bentuk aktivitas fisik yang dinamakan olahraga (Qomarrullah, 2015). Pendidikan jasmani bagian yang tidak terpisahkan dari pendidikan nasional yang bertujuan untuk pengembangkan kemampuan peserta didik melalui aktivitas jasmani (Utama Bandi, 2011). Sehingga pendidikan jasmani harus diajarkan kepada setiap peserta didik pada semua jenjang pendidikan.

Pendidikan jasmani pada dasarnya merupakan bagian integral dari sistem pendidikan secara keseluruhan, bertujuan untuk mengembangkan aspek kesehatan, kebugaran jasmani, ketrampilan berfikir kritis, stabilitas emosional, ketrampilan sosial, penalaran dan tindakan moral melalui aktivitas jasmani dan olahraga. Pendidikan jasmani pada dasarnya merupakan pendidikan melalui aktivitas jasmani untuk mencapai perkembangan individu secara menyeluruh (Adang Suherman dan Agus Mahendra, 2002). Pendidikan jasmani adalah suatu proses melalui aktivitas jasmani yang desain untuk meningkatkan kebugaran jasmani, mengembangkan ketrampilan motorik, pengetahuan dan perilaku hidup sehat dan aktif, sikap sportif, dan kecerdasan emosi.

Lingkungan belajar diatur secara seksama untuk meningkatkan pertumbuhan dan perkembangan seluruh ranah, yaitu jasmani, psikomotor, kognitif dan afektif, karenanya pendidikan jasmani ini harus menyebabkan perbaikan dalam pikiran (psikis) dan tubuh (fisik) yang mempengaruhi seluruh aspek kehidupan harian seseorang. Pendekatan holistik tubuh jiwa ini termasuk pula penekanan pada ketiga dominan kependidikan: psikomotor, kognitif, afektif. Pendidikan jasmani diharapkan mampu menciptakan tubuh yang baik bagi pikiran atau jiwa. Pendidikan jasmani merupakan bagian integrasi pendidikan keseluruhan yang bertujuan meningkatkan individu secara organik, muskuler, intelektual dan emosional melalui aktivitas jasmani (Harsuki, 2003).

Untuk mencapai semua tujuan dari pendidikan jasmani tersebut maka diperlukan peran guru yang kreatif dalam mengemas proses pembelajaran penjas, sehingga hambatan dalam proses pembelajaran penjas dapat diminimalisasi. Hambatan yang sering dialami dalam kegiatan proses belajar penjas adalah minat siswa yang rendah, lingkungan belajar yang kurang baik dan masalah ketersediaan sarana dan prasarana yang ada disekolahan. Guru yang kreativitasnya baik akan membuat proses pembelajaran menjadi lebih menarik, menyenangkan dan membuat siswa menjadi mudah dalam menyerap materi yang disampaiakan. Begitu juga sebaliknya guru dengan kreativitas yang tidak baik akan menjadikan tujuan pembelajaran penjas tidak tercapai (Wicaksono, 2019)

Perencanaan pendidikan jasmani dilakukan secara seksama untuk memenuhi perkembangan, pertumbuhan, dan kebutuhan perilaku setiap anak. Maka pendidikan jasmani bukan hanya ditujukan untuk mengembangkan kemampuan psikomotorik, akan tetapi juga mengembangkan kemampuan kognitif dan afektif peserta didik (Paramitha, 2018). 
Pendidikan Jasmani yang diajarkan di sekolah memiliki peranan sangat penting, karena dapat memberikan kesempatan kepada peserta didik untuk terlibat langsung dalam berbagai pengalaman belajar melalui aktivitas jasmani yang dilakukan secara sistematis. Pembekalan Pendidikan Jasmani di sekolah diperlukan untuk memberikan kesempatan siswa dalam membina pertumbuhan fisik dan pengembangan psikis yang lebih baik, seperti yang disebutkan oleh Husdarta (2009: 3) yaitu "Pendidikan Jasmani melibatkan aktivitas fisik dan kesehatan untuk menghasilkan perubahan holistic dalam kualitas individu, baik dalam hal fisik, mental serta emosional" (Hasan, 2015)

Mendapatkan kehidupan yang cerdas harus memiliki pendidikan, dengan pendidikan, orang tentu memiliki ilmu pengetahuan luas serta dapat meningkatkan kualitas. Kualitas pembelajaran harus ditingkatkan dalam pembelajaran pendidikan jasmani, holahraga dan kesehatan (PJOK). PJOK yakni kegiatan yang mengembangkan aspek kebugaran jasmani untuk menjaga kebugaran tubuh. Proses PJOK ini sangat bagus diterapkan di sekolah untuk kelangsungan belajar dari peserta didik. Untuk sekarang pelaksanaan pembelajaran di sekolah masih belum bisa dilaksanakan secara efektif dan efesien, hal ini disebabkan karena terjadinya kasus pandemi saat ini dan proses pembelajaran disekolah masih menggunakan sistem online atau daring yang diakibatkan adanya kasus covid-19.

Kasus covid-19 sudah tidak asing lagi untuk didengar bukan hanya di indonesia tetapi di dunia sudah mengetahui kasus covid-19. Virus ini begitu cepat penyebaranya khususnya bagi orang yang sudah mempunyai penyakit bawaan dari lahir dan itu mempermudah virus untuk masuk kedalam tubuh apabila tidak melakukan prilaku hidup sehat. Covid-19 mengakibatkan banyak negara melaksanakan lockdowm, social distancing, dan isolasi, hingga karantina dan itu sebagai upaya agar virus corona atau covid-19 mampu memperlambat angka penyebaran. Virus Corona begitu bahaya di kalangan masyarakat dalam proses penularannya. Gejala yang timbul begitu sulit untuk di identifikasi. Sebaliknya orang yang tidak memiliki suatu gejala tentu sudah terinfeksi. Oleh sebab itu orang yang sudah terinfeksi lebih sering menularkan ke orang lain tanpa mengetahui bahwa sudah terinfeksi. Dengan adanya virus ini sangat berdampak besar bagi sekolah khususnya yang berminat mengikuti pembelajaran PJOK, minat pembelajaran PJOK yakni keinginan yang dimiliki dari dalam untuk menemukan kesenangan (Kasim, 2011). Oleh sebab itu peserta didik harus memperhatikan setiap proses pembelajaran.

Peserta didik yang kurang memperhatikan proses pembelajaran tentu minatnya rendah, dengan didukung pendapat dari Slameto, 2010 (dalam Dewa, dkk. 2020) peserta didik yang kurang memperhatikan pembelajaran menunjukkan kurangnya minat pembelajaran PJOK. Sehingga peserta didik begitu kesulitan belajar PJOK. Tentu menyebabkan kurangnya pengawasan dari guru dalam proses pembelajaran secara online. Karena guru PJOK memiliki tugas untuk membimbing dan mengarahkan agar tidak terjadi kesalahan pada peserta didik. Akibat adanya covid-19 peserta didik tidak bisa mengikuti pembelajaran disekolah seperti biasa, dimana pembelajaran PJOK harus diberikan kepada peserta didik walaupun secara online.

Minat yaitu rasa ketertarikan yang timbul didalam diri seseorang tanpa ada dorongan dari siapapun untuk mengikuti aktivitas (Slameto, 2015). Sedangkan peserta begitu dituntut untuk mengikuti proses pembelajaran baik individu maupun kelompok dan tentu harus sesuai dengan hoby dan keinginan masing-masing peserta itu, hal ini didukung oleh Mustari, 2015 (dalam Kirom 2017) menyatakan peserta didik yakni seseorang individu yang berhak memperoleh pelayanan bagus yang tentunya agar orang itu memperoleh kepuasan dalam menerima pelayanan.

PJOK merupakan pembelajaran yang meningkatkan kebugaran jasmani yang melalui aktivitas (Mashud, 2018). PJOK merupakan pembelajaran yang tidak dapat dipisahkan dari pendidikan. Dimasa pandemi ini virus covid-19 begitu maraknya dikalangan masyarakat 
dunia karena bisa mengancam kesehatan seseorang dan melumpukan perekonomian masyarakat (Purwanto, 2020). Virus Covid-19 ini menyebabkan krisis bagi dunia yang menyebabkan lumpuhnya perekonomian di masyarakat.

Dimasa pandemi covid-19 pembelajaran daring menjadi solusi utama bagi dunia pendidikan. Dalam sistem pembelajaran PJOK yang berlangsung hal pertama yang dilakukan guru yakni mengabsen peserta didik berapa orang yang hadir dan tidak hadirnya dan sistem yang digunakan masih dalam sistem online, setelah mengabsen guru memberikan materi pada peserta didik ,selesai menginformasikan guru menugaskan untuk membuat tugas sesuai dengan materi yang disampaikan di grup kelas, setelah diberikan tugas guru kembali menginformasikan bahwa tugasnya dikirim melalui individu kepihak guru dan sistem penilaian akan diinformasikan digrup kelas. Dengan sistem pembelajaran yang diterapkan masih belum efektif dan efesien. Tujuan penelitian ini adalah untuk mengetahui minat peserta didik kelas VIII di SMP Negeri 5 Singaraja dalam mengikuti pembelajaran PJOK pada masa pandemi covid-19.

\section{Metode}

Penelitian ini dilakukan untuk menguji minat peserta didik kelas VIII di SMP Negeri 5 Singaraja dalam mengikuti pembelajaran PJOK pada masa pandemi covid-19. Variabel dalam penelitian terdiri dari variabel bebas dan variabel terikat. Variabel bebas yaitu minat peserta didik dalam mengikuti pembelajaran PJOK Sedangkan variabel terikatnya yaitu Pandemi Covid-19. Berdasarkan karakteristik masalah yang diteliti penelitian ini menggunakan statistik deskriptif kuantitatif kemudian dikategorikan berdasarkan skala penilaian. Subjek dalam penelitian ini adalah seluruh peserta didik kelas VIII di SMP Negeri 5 singaraja, objek penelitian ini SMP Negeri 5 Singaraja.

Populasi yang digunakan dalam penelitian ini adalah seluruh peserta didik di SMP Negeri 5 Singaraja yang berjumlah 300 orang Penelitian ini dikategorikan sebagai jenis penelitian deskriptif dengan pendekatan kuantitatif. Metode pengumpulan data menggunakan metode survey, sedangkan jenis survey yang digunakan yaitu survey kuisioner yang dijawab oleh peserta didik.

Teknik pengumpulan data yang digunakan pada penelitian ini yaitu kuesioner. Kuesioner adalah metode pengumpulan data yang berupa daftar rangkaian atau kumpulan pernyataan yang ditunjukan kepada setiap responden yang telah disusun secara sistematis untuk mendapatkan jawaban yang berkaitan dengan data yang dibutuhkan dalam suatu penelitian. Salah satu skala yang umum dipakai dalam penyusunan kuesioner adalah Skala Likert, yaitu skala yang berisi lima tingkat jawaban yang disusun dalam bentuk suatu pernyataan dan diikuti oleh lima respon yang menunjukan tingkatan. Metode analisis yang digunakan dalam penelitian ini adalah analisis deskriptif. Analisis perlu dilakukan agar dapat mengetahui minat pembelajaran PJOK dimasa pandemi. Kemudian penelitian ini menggunakan instrument yang berupa angket yang telah diuji oleh ahli.

\section{Hasil dan Pembahasan}

Hasil analisis minat peserta didik dalam mengikuti pembelajaran PJOK di Kelas VIII SMP Negeri 5 Singaraja tersaji pada Tabel 1 berikut ini. 
Tabel 1. Analisis Peryataan

\begin{tabular}{|c|c|c|c|c|c|c|c|c|}
\hline $\mathrm{NO}$ & Pernyataan & SR & $\mathrm{R}$ & $\mathrm{T}$ & ST & Nilai & $\begin{array}{l}\text { Rata - } \\
\text { Rata }\end{array}$ & Kategori \\
\hline 1 & $\begin{array}{l}\text { Minat saya } \\
\text { melakukan } \\
\text { aktivitas gerak } \\
\text { pada masa } \\
\text { pandemic covid - } \\
19 \text { untuk menjaga } \\
\text { kebugaran }\end{array}$ & 0 & 0 & 27 & 33 & 60 & 89 & $\begin{array}{l}\text { Sangat } \\
\text { Tinggi }\end{array}$ \\
\hline 2 & $\begin{array}{l}\text { Saya berminat } \\
\text { untuk mengikuti } \\
\text { pembelajaran } \\
\text { PJOK dengan } \\
\text { benar dan muah }\end{array}$ & 2 & 0 & 19 & 33 & 60 & 90 & $\begin{array}{l}\text { Sangat } \\
\text { Tinggi }\end{array}$ \\
\hline 3 & $\begin{array}{l}\text { Saya tidak } \\
\text { berminat untuk } \\
\text { belajar PJOK }\end{array}$ & 19 & 38 & 2 & 1 & 60 & 81 & $\begin{array}{l}\text { Sangat } \\
\text { Tinggi }\end{array}$ \\
\hline 4 & $\begin{array}{l}\text { Saya berminat } \\
\text { untuk } \\
\text { memperhatikan } \\
\text { teknik - teknik } \\
\text { yang di jelaskan }\end{array}$ & 1 & 1 & 33 & 25 & 60 & 84 & $\begin{array}{l}\text { Sangat } \\
\text { Tinggi }\end{array}$ \\
\hline 5 & $\begin{array}{l}\text { Saya berminat } \\
\text { mengikuti } \\
\text { pembelajaran } \\
\text { PJOK karena } \\
\text { dapat } \\
\text { meningkatkan } \\
\text { kesehatan }\end{array}$ & 3 & 9 & 39 & 9 & 60 & 72 & $\begin{array}{l}\text { Sangat } \\
\text { Tinggi }\end{array}$ \\
\hline 6 & $\begin{array}{lr}\begin{array}{l}\text { Saya } \\
\text { senang }\end{array} & \text { merasa } \\
\text { melakukan } & \\
\text { aktivitas } & \text { jasmani } \\
\text { pada } & \text { masa } \\
\text { pandemic } & \text { covid - } \\
19 & \end{array}$ & 0 & 0 & 30 & 30 & 60 & 88 & $\begin{array}{l}\text { Sangat } \\
\text { Tinggi }\end{array}$ \\
\hline 7 & $\begin{array}{l}\text { Saya tidak } \\
\text { berminat } \\
\text { mengikuti } \\
\text { pembelajaran } \\
\text { PJOK }\end{array}$ & 0 & 3 & 38 & 19 & 60 & 82 & $\begin{array}{l}\text { Sangat } \\
\text { Tinggi }\end{array}$ \\
\hline 8 & $\begin{array}{l}\text { Saya sangat } \\
\text { tertarik mengikuti } \\
\text { pembelajaran } \\
\text { PJOK }\end{array}$ & 0 & 3 & 46 & 11 & 60 & 78 & $\begin{array}{l}\text { Sangat } \\
\text { Tinggi }\end{array}$ \\
\hline 9 & $\begin{array}{ll}\text { Saya } & \text { sangat } \\
\text { senang } & \text { dalam } \\
\text { melakukan } & \\
\end{array}$ & 2 & 7 & 37 & 13 & 60 & 76 & $\begin{array}{l}\text { Sangat } \\
\text { Tinggi }\end{array}$ \\
\hline
\end{tabular}




\begin{tabular}{|c|c|c|c|c|c|c|c|c|c|}
\hline & $\begin{array}{l}\text { aktivitas } \\
\text { pada } \\
\text { pandemic } \\
19\end{array}$ & $\begin{array}{r}\text { jasmani } \\
\text { masa } \\
\text { covid - }\end{array}$ & & & & & & & \\
\hline 10 & $\begin{array}{l}\text { Saya } \\
\text { berminat } \\
\text { aktivitas } \\
\text { yang } \\
\text { dilakukan }\end{array}$ & $\begin{array}{r}\text { tidak } \\
\text { dengan } \\
\text { jasmani } \\
\text { sulit }\end{array}$ & 8 & 38 & 11 & 3 & 60 & 71 & $\begin{array}{l}\text { Sangat } \\
\text { Tinggi }\end{array}$ \\
\hline
\end{tabular}

Berdasarkan hasil analisis dari jawaban responden, 10 pernyataan minat bila dirataratakan memperoleh hasil yaitu 81. Bila dikonversikan dalam tabel interval skor pada pernyataan minat faktor intrinsik berada pada kategori sangat tinggi. Penelitian ini didukung dengan beberapa penelitian yang relevan yaitu, pertama penelitian yang dilakukan oleh (Setiadi, 2017). yang menunjukkan bahwa minat siswa kelas VIII dalam mengikuti pembelajaran PJOK di SMP Negeri 2 Godean Kabupaten Sleman Daerah Istimewa Yogyakarta adalah sedang. Kedua penelitian yang dilakukan oleh (Adi Nugroho, 2011) yang memperoleh hasil penelitian bahwa minat siswa terhadap pembelajaran penjas dengan menggunakan modifikasi permainan bola voli pada siswa kelas VIII SMP 2 kaliwiro kab. Wonosobo tahun pelajaran 2010/2011 dalam kategori tinggi.

\section{Simpulan}

Berdasarkan pembahasan diatas dapat disimpulkan bahwa minat peserta didik dalam mengikuti pembelajaran PJOK pada masa pandemic Covid-19 di kelas VIII SMP Negeri Singaraja adalah sangat tinggi.

Berdasarkan hasil pembahasan dan simpulan yang telah dikemukakan, maka saran yang dapat dianjurkan sebagai berikut. 1) Bagi peserta didik diharapkan dapat mempertahankan minat pembelajaran PJOK. 2) Bagi peneliti selanjutnya, dapat menggunakan penelitian ini sebagai referensi dalam penelitian. 3) Bagi guru dapat dijadikan pedoman dalam pembelajaran PJOK.

\section{Daftar Pustaka}

Adi Nugroho, Y. (2011). Minat Siswa Terhadap Permainan Bola Voli Modifikasi Dalam Pembelajaran Penjasorkes Pada Siswa Kelas VIII Di SMP 2 Kaliwiro Kab. Wonosobo”. Fakultas Keolahragaan. Universitas Negeri Semarang.

Hasan, S. (2015). Pengembangan Model Permainan Gerak Dasar Lempar Untuk Siswa Kelas V Sdn Tawangargo 4 Karangploso Malang. Jurnal Pendidikan Olahraga, 4(2).

Kasim, M. (2011). Pentingnya Motivasi dan Minat Terhadap Manajemen Kinerja Guru Dalam Pelaksanaan Pembelajaran Pendidikan Jasmani, Olahraga dan Kesehatan. ACADEMICA Fisip Untad. Retrieved from http://jurnal.untad.ac.id/jurnal/index.php/academica/article/download/2285/1478

Mashud. (2018). Analisis Masalah Guru PJOK Dalam Mewujudkan Tujuan Kebugaran Jasmani”. Universitas Lambung Mangkurat. Retrieved from https://ppjp.ulm.ac.id/journal/index.php/multilateralpjkr/article/view/5704/4778

Paramitha, S. T. (2018). Revitalisasi Pendidikan Jasmani untuk Anak Usia Dini melalui Penerapan Model Bermain Edukatif Berbasis Alam. Jurnal Pendidikan Jasmani Dan Olahraga JPJO, 3(1), 41-51.

Purwanto, dkk. (2020). Studi Eksploratif Dampak Pandemi Covid-19 Terhadap Proses Pembelajaran Online di SD". Universitas Pelita Harapan Indonesia. Retrieved from https://ummaspul.e-journal.id/Edupsycouns/article/view/397/223 
Qomarrullah, R. (2015). Model Aktivitas Belajar Gerak Berbasis Permainan Sebagai Materi Ajar Pendidikan Jasmani. Journal of Physical Education, Health and Sport, 2(2).

Setiadi, L. R. (2017). Minat Siswa Kelas VIII Dalam Mengikuti Pembelajaran Pjok Di SMP Negeri 2 Godean Kab. Sleman Daerah Istimewa Yogyakarta. Retrieved from http://journal.student.uny.ac.id/ojs/index.php/pjkr/article/download/9352/9020

Slameto. (2015). Metodelogi Penelitian \& Inovasi Pendidikan. Salatiga:Cipta.

Wicaksono, G. H. (2019). Kreativitas Guru Penjas Terhadap Proses Pembelajaran Penjas Di Sekolah Menengah Pertama Negeri Sekecamatan Kebumen Kabupaten Kebumen 2018. Jurnal Pendidikan Kesehatan Rekreasi, 5(2), 95-100.

Wirayasa, I. D. G. P. (2020). Pengembangan Instrumen Penilaian Hasil Belajar Ranah Kognitif Model 4d Pada Materi Sepak Bola Berdasarkan Kurikulum 2013. Jurnal Pendidikan Jasmani Olahraga Dan Kesehatan, 8(3). 